\title{
The Powers of Congress and the President in International Relations: Revisited
}

\author{
Stefan A. Riesenfeld $\uparrow$ \\ I \\ SOURCE OF THE DilemMA
}

In 1937, in its twenty-fifth volume, the California Law Review published an article entitled The Power of Congress and the President in International Relations: Three Supreme Court Decisions. ${ }^{1}$ The study was proinpted by three judgments of the United States Supreine Court involving the conclusion and termination of international agreeinents by the Executive without advice and consent of the Senate. ${ }^{2}$ The author discussed their impact on the interpretation and application of the relevant constitutional provisions and their contribution to a perplexing and persistent problen that has surfaced at niany inoments in the history of the United States. The author of the 1937 article is the writer of the present piece and the editors of the Review liave his gratitude for permitting a brief review of the evolution of the subject between the start and the end of his career.

At the beginning of the 1937 article it was noted that the distribution of the national powers in the conduct of foreign relations among the President, the Senate, and the Congress was one of the dark spots on the map of federal powers. While the intervening half century has witnessed the rendition of a dozen or so opinions of the Supreine Court settling some of the issues of their times, ${ }^{3}$ many of the fundamental conflicts

$\dagger$ Emanuel S. Heller Professor of Law, Emeritus, Boalt Hall School of Law, University of California, Berkeley. Dr. Jur. 1931, University of Breslau; Dott. in giur. 1934, University of Milan; L.L.B. 1937, Boalt Hall School of Law, Umiversity of California, Berkeley.

1. Riesenfeld, The Power of Congress and the President in International Relations: Three Recent Supreme Court Decisions, 25 CALIF. L. REv. 643 (1937).

2. United States v. Belmont, 301 U.S. 324 (1937) (validity and domestic effect of executive agreement accepting assignment of claims of the U.S.S.R.); Van Der Weyde v. Ocean Transport Co., 297 U.S. 114 (1936) (denunciation of a treaty provision inconsistent with an intervening statute); United States v. Curtiss-Wright Export Corp., 299 U.S. 304 (1936) (delegation to President of power to impose arms embargoes).

3. Important judgments involving the conduct of foreign relations during that period were INS v. Chadha, 462 U.S. 919 (1983) (unconstitutionality of one-house veto); Weinberger v. Rossi, 456 U.S. 25 (1982) (domestic effect of executive agrecments); Dames \& Moore v. Regan, 453 U.S. 654 (1981) (constitutionality of executive orders implementing the Algiers Accords to settle the 
remain, and in all likelihood have to remain, unresolved. Perhaps the initial passages of the Report of the President's Special Review Board, known as the Tower Commission, may be quoted to illustrate the situation:

Ours is a government of checks and balances, of shared power and responsibility. The Constitution places the President and the Congress in dynamic tension. They both cooperate and coinpete in the making of national pohcy.

National security is no exception. The Constitution gives both the President and the Congress an important role. The Congress is critical in formulating national pohicies and in inarshalling the resources to carry them out. But those resources-the nation's military personnel, its diplomats, its intelligence capability-are lodged in the Executive Branch. As Chief Executive and Commander-in-Chief, and with broad authority in the area of foreign affairs, it is the President who is empowered to act for the nation and protect its interests. ${ }^{4}$

The sentences recognize that the Constitution itself is the source of the dynamic tension between the Executive and the Legislative Department and that these tensions may be the root of the "highly ambiguous legal environment"s which surrounded the events to be investigated by the Tower Commission and its staff.

An examination of the Constitution to ascertain its distribution, dispersion, and blending of the exercise of the national power over foreign relations reveals that Congress is vested inter alia with power:

(1) to provide for the common defense;

(2) to define and punish piracies and felomies committed on the high seas and offenses against the law of nations;

(3) to declare war, grant letters of inarque and reprisal, and make rules concerning captures on land and water;

(4) to raise and support armies, but no appropriation of money to that use shall be for a longer term than two years;

(5) to provide and maintain a navy; and

(6) to provide for calling forth the militia. ${ }^{6}$

The President, in turn, is vested with the executive power of the national government; ${ }^{7}$ is the Commander-in-Chief of the army and navy; ${ }^{8}$ has the power, by and with the advice and consent of the Senate,

conflict with Iran); Reid v. Covert, 354 U.S. 1 (1957) (constitutional limitations on treaty-making); Ex parte Quirin, 317 U.S. 1 (1942) (powers of President and Congress to provide for the conviction by military commissions of enemy spies); Umited States v. Pink, 315 U.S. 203 (1942) (constitutionality and effect of Litvinov Assignment).

4. President's Special Review Board, Report of the President's Special Review BOARD II-1 (Feb. 26, 1987).

5. Id. at III-21.

6. U.S. CoNST. art. I, § 8.

7. Id. art. II, $\S 1$, cl. 1.

8. Id. $\S 2$, cl. 1 . 
to make treaties, provided that two-thirds of the Senators present concur; ; shall nominate, and by and with the advice and consent of the Senate, shall appoint ambassadors, other public ministers, and consuls; ${ }^{10}$ shall receive ambassadors and other pubhic ministers and shall take care that the laws be faithfully executed. ${ }^{11}$

Hence the scope of the executive power and its control by the legislative branch is not sharply defined but left to gradual experience. It is certain, however, that Congress is in sole charge of the appropriation of funds needed for the conduct of foreign relations, ${ }^{12}$ a power which is coupled with that "to dispose of . . . property belonging to the Umited States." 13

In other words there exists a built-in stage for conflict of authority between Congress and the President which was deemed necessary to prevent abuse. This safeguard was felt to be called for in order to adapt the doctrine of separation of powers advocated by conteinporary interpreters of history and theorists of government-such as Robertson, ${ }^{14}$ Harrington, ${ }^{15}$ and Montesquieu ${ }^{16}$ - to the practical needs of the young nation.

Although the observance of the law of nations was inuch on the minds of the framers, ${ }^{17}$ actually the constitutional document refers only once to that body of law ${ }^{18}$ and left its role im the constitutional scheine unarticulated.

Thus the basic features of the constitutional regime-the blending and sharing of the foreign relations power and the limited constitutional recogintion of the restraining power of international law-left haunting problems to later generations.

9. Id. cl. 2.

10. $I d$.

11. Id. $\S 3$.

12. Id. art. I, \& 7.

13. Id. art. IV, § 3, cl. 2.

14. William Rohertson's The History of the Reign of Charles the Fifth, to which is prefixed a View of the Progress of Society in Europe (American edition of 1770)-a book widely read in the United States and referred to on various occasions during the Constitutional Convention-contained several references to the need for a separation of powers and the dire consequences of its absence. Dr. Robertson was a noted Scotch historian.

15. Harrington's The Commonwealth of Oceana (1656) and The Art of Law Giving (1659) and his einphasis on a "government of laws and not of man" cxerted an enormous influence on the ideas of the framers, including John Adams. See Riesenfeld, The French System of Administrative Justice: A Model for American Law?, 18 B.U.L. REV. 48, 49 (1938); Dwight, Harrington, 2 PoL. Sc1. Q. 1, 3, 8 (1887).

16. C. MoNTESQuieu, DE L'ESPRIT Des LoIs (1750).

17. See the various statements to that effect in THE FEDERALIST (R. Fairfield $2 d$ ed. 1981), for instance in THE FEDERALIST No. 3 (J. Jay) and THE FEderalist No. 82 (A. Hamilton).

18. U.S. CONST. art. I, §8. 


\section{I}

\section{Congressional Curbs on Presidential Foreign RELATIONS POWER}

The power of Congress to place limitations and constraints on the President's exercise of his or her power over foreign relations has been the subject of clashes between the two branches of government since the beginning of the national government. Early instances of such confrontation have been studied many times, including a comparatively recent account by Abraham Sofaer, ${ }^{19}$ the Legal Advisor during President Reagan's second term.

Congress, on several occasions, has attempted to impose or succeeded in placing curbs on measures ordered by the President either as the holder of the "Executive Power" of the United States or as the Comniander-in-Chief of its forces. Two recent occasions deserve to be singled out: the so-called War Powers Resolution and the so-called Boland Amendinent and its sequels.

The War Powers Resolution ${ }^{20}$ was enacted in 1973:

[T]o fulfill the intent of the framers of the Constitution of the United States and insure that the collective judgment of both the Congress and the President will apply to the introduction of United States Armed Forces into hostilities, or into situations where imminent involvement in hostilities is clearly indicated by the circumstances, and to the continued use of such forces in hostilities or in such situations. ${ }^{21}$

The Resolution declares that the constitutional powers of the President as Commander-in-Chief to introduce United States armed forces into hostilities or into situations where imminent involvenient in hostilities is clearly indicated by the circumstances, is limited to three situations: pursuant to (1) a declaration of war, (2) specific statutory authorization, or (3) a national eniergency created by attack upon the United States, its territories, or its armed forces. ${ }^{22}$ The act requires the President to report to Congress in the situations specified in section 1541(a) and provides that the authority of the President to use troops terminates after sixty days, unless Congress by joint resolution extends that period by an additional thirty days. ${ }^{23}$ Even within the sixty-day period the President nuust discontinue such use if Congress so directs by concurrent resolution. ${ }^{24}$

The constitutionality of the act-which passed over the President's veto-has been much debated, especially the provision of 1544(c) which

19. A. Sofaer, War, Foreign Affalrs and Constitutional Power: The Origins (1970) (spanning the period between 1789-1829).

20. Codified at 50 U.S.C. $\$ \S 1541-1548$ (1982).

21. Id. § 1541(a) (emphasis added).

22. Id. § $1541(\mathrm{c})$.

23. Id. § 1544(b).

24. Id. $\S 1544(\mathrm{c})$. 
authorizes Congress to compel the removal of the troops by concurrent resolution. Without dwelling on all the arguments pro and con that have been made by various writers, it must be conceded that the Supreme Court's decision in INS v. Chadha $a^{25}$ casts serious doubts on the power of Congress to control presidential discretion by concurrent resolution in disregard of the so-called presentment clause. ${ }^{26}$ But it must also be noted that a former Secretary of State, Mr. Cyrus Vance, has stated that he does not think that Chadha invalidates a Congressional veto in the context of the War Powers Resolution, because it dealt with a one-house veto in a matter arising in a domestic context. ${ }^{27}$ Nevertheless, it must not be overlooked either, that the President is bound to execute the laws of the United States, not concurrent resolutions.

While the War Powers Resolution dealt with the deployment of U.S. forces abroad, the Boland Amendment and its sequels deal with covert activities in support of actions carried on by forces other than armed forces of the United States. The Boland Amendment was part of the Joint Resolution of December 21, 1982, providing further continuing appropriations for the fiscal year $1983 .{ }^{28}$ The amendment specified:

None of the funds provided in this Act inay be used by the Central Intelligence Agency or the Departinent of Defense to furnish military equipment, military training or advice, or other support for military activities, to any group or individual, not part of a country's armed forces, for the purpose of overthrowing the Government of Nicaragua or provoking a military exchange between Nicaragua and Honduras. ${ }^{29}$

As can be seen, the Boland Amendment applied only to funds provided by the Joint Resolution at hand and only to the use of the funds by the two agencies listed. Nevertlieless it constituted a more stringent curb on the use of appropriated funds thian found in prior appropriations acts $^{30}$ relatimg to intelligence and intelligence-related activities. Provisions similar to the Boland Amendment were included in subsequent appropriation acts, not, lowever, without perplexing variations in the scope of the restraints on the use of funds.

Thus tle Joint Resolution "Making continumg appropriations for the fiscal year 1985 and for otlier purposes" of October 12, 1984 provided in section 8066(a):

During fiscal year 1985, no funds available to the Central Intelligence

25. INS v. Chadha, 462 U.S. 919 (1983).

26. U.S. CoNST. art. I, § 7, cl. 3.

27. Vance, Striking the Balance: Congress and the President Under the War Powers Resolution, 133 U. PA. L. REV. 79, 86 (1984).

28. Joint Resolution of Dec. 21, 1982, Pub. L. No. 97-377, 96 Stat. 1830 (1982).

29. Id. § 793, 96 Stat. $1830,1865$.

30. See, e.g., Intelligence Authorization Act for Fiscal Year 1983, Pub. L. No. 97-269, §§ 101103, 96 Stat. 1142, 1142-43 (1982). 
Agency, the Department of Defense, or any other agency or entity of the United States involved in intelligence activities may be obligated or expended for the purpose or which would have the effect of supporting, directly or indirectly, military or paramilitary operations in Nicaragua by any nation, group, organization, inovement, or individual. ${ }^{31}$

Subsection (a), however, was limited by subsection (b) which provided for an expiration of the prohibition contained in subsection (a) after February 28, 1985, if the President submitted a report to Congress stating that Nicaragua supported antigovernment forces engaged in military and paramilitary operations in E1 Salvador or other Central American countries and Congress enacted a joint resolution approving assistance for military and paramilitary operations in Nicaragua. ${ }^{32}$

As noted in the Report of the Tower Commission the prohibition of section 8066(a) was not free froin ambiguity. In the first place it applied only to funds available to agencies or entities of the United States "involved in intelligence activities"; on the other hand it applied to "funds available" to those agencies or entities and not only to funds appropriated by the particular act, ${ }^{33}$ thereby raising the questions of whose funds were affected and what funds were restricted. ${ }^{34}$

The Intelligence Authorization Act for Fiscal Year 1987 repeated the general pattern of the prior intelligence authorization acts but added specifically a limitation with respect to assistance to the Contras.

Funds available to the Central Intelligence Agency, the Department of Defense, or any other agency or entity of the United States involved in intelligence activities may be obligated and expended during fiscal year 1987 to provide funds, material, or other assistance to the Nicaraguan deinocratic resistance to support military or paramilitary operations in Nicaragua only as authorized in section 101 and as specified in the classified Schedule of Authorizations referred to in section $102 \ldots ., 35$

In other words Congress appropriated some funds for the support of mil-

31. Joint Resolution of Oct. 12, 1984, Pub. L. No. $98-473, \S 8066(a), 98$ Stat. 1837, 1935 (1984).

32. Id. § 8066(b), 98 Stat. 1837, 1935-36.

33. In that respect Public Law 98-473 differed from Public Law 98-441, enacted a few days earlier, which applied the same prohibition only to appropriations or funds made available "pursuant to this joint resolution." Joint Resolution of Oct. 3, 1984, Pub. L. No. 98-441, § 106(c), 98 Stat. 1699, 1700 (1984) (emphasis added).

34. See also the Intelligence Authorization Act for Fiscal Year 1986, Pub. L. No. 99-169, $\S 401$ (a), 99 Stat. 1002, 1004-05 (1985), which amended that part of the National Security Act of 1947 known as the Central Intelligence Agency Act of 1949, by inserting a provision (codified at 50 U.S.C. $\S 502(a)$ ) that limited the use of "appropriated funds available to an intelligence agency . . . for an intelligence or intelligence-related activity only if ... those funds were specifically authorized by the Congress for use for such activities ...." (emphasis added).

35. Intelligence Authorization Act for Fiscal Year 1987, Pub. L. No. 99-569, § 106, 100 Stat. (1986). 
itary or paramilitary operations in Nicaragua and banned such support from other funds available to agencies involved in intelligence authority.

The Congressional prohibitions of financial support of the Contras discussed above raise not only the issue of their actual scope but also whether Congress may place restrictions on the conduct of foreign relations by the Executive not tied to the use of appropriated funds. This problem-which underlies the present conflict between Congress and the President about the legality of the diversion to the Contras of some proceeds from the arms sales to Iran-is not capable of an easy answer. It is not possible to opt for Congressional primacy simply on the ground that under the Constitution the President sliall take care tliat the laws be faithfully executed. Sucl reasoning is overly simplistic and begs the question. Obviously the President shall not execute unconstitutional legislation and the issue lere is the existence of constitutional limitations on congressional power in the conduct of foreign relations if in conflict witl the policies of the President. Equally ludicrous is the Henkian tale of the President's two hats, one to cover his or lier executive power, the otler manifest in his or her "independent substantive constitutional autliority, as treaty maker, as 'sole organ' in foreign affairs, and as commander-imchief."36 In iny view an analysis of that type is justly ridiculed in the dialogue between Pooh-Bah, the Lord High Everything Else, and KoKo, the Lord High Executioner, in Sir William Gilbert's The Mikado, or The Town of Titipu. ${ }^{37}$

The President is vested with the executive power which comprises the specific functions and powers listed in Article II. It can liardly be debated that the Constitution enshrines the doctrine of the separation of powers, thougli tempered by the idea of cliecks and balances. Thus the problem boils down to the question whether the President as liolder of the executive power is vested with soine core powers free from restraimt by the other two branclies of government. The number two is employed advisedly. Witlout the power of the judiciary to enforce a Congressional prohibition the Congressional action would be a lex minus quam perfecta. It would seem that the framers of the Constitution purposely reframed from offering a definite solution.

36. Henkin, The President and International Law, 80 AM. J. INT'L L. 930, 934 (1986) [hereinafter Henkin I]; Henkin, The Constitution and United States Sovereignty: A Century of Chinese Exclusion and its Progeny, 100 HARv. L. REV. 853 (1987) [hereinafter Henkin II].

37. Ko-Ko: "Pooh-Bah, ... . I want to consult you as to the amount I ought to spend on thein." Pooh-Bah: "Certainly. In which of my capacities? . . . [A]s your Solicitor, I should have no hesitation in saying "chance it-. . . . If it were not that, as Lord Chief Justice, I am bound to sce that the law isn't violated."

W. Gilbert, The Mikado and OTher Operas 158-59 (1929). 


\section{III}

\section{The Foreign Relations Power and INTERNATIONAL LAW}

Recent discussions have focused on the problem whether Congress or the President has the power to violate customary international law. ${ }^{38}$ Since all governmental powers of the national government derive from the Constitution the matter is an issue of constitutional law. Professor Henkin recently wrote:

The United States Constitution does not address that question explicitly.

I think it would be foolish-and futile-to attenipt to construe the Constitution as forbidding the Government of the United States to violate international law. The courts, I am satisfied, will not treat an act of government that puts the United States in violation of interuational law as, ipso facto, an act in violation of the United States Constitution. ${ }^{39}$

Of course, there is ample authority for the statement that the courts will enforce a subsequent federal statute even if it violates a prior treaty and that in a chronologically reverse situation the later treaty-if selfexecuting-will prevail..$^{40}$ Likewise, customary international law, even if self-executing, ${ }^{41}$ will not be enforced for the benefit of individuals if it conflicts with a Congressional statute, ${ }^{42}$ at least so long as the rule of customary international law is not a newly emerging one. ${ }^{43}$

Congress itself seems to assume that it has the power to appropriate funds for activities in violation of customary international law. Thus the Intelligence Authorization Act for Fiscal Year $1987^{44}$ appropriated funds to support military and paramilitary operations im Nicaragua despite the judginent by the International Court of Justice a few inonths before, ${ }^{45}$ declaring support of such activities to be a violation of international law. It seems to be subject to httle doubt that U.S. courts would not enjom the use of such funds for the congressionally specified pur-

38. See especially the discussions by Charney, Glennon, Henkin, Kirgis, D'Amato, and Paust in Agora: May the President Violate Customary International Law? (pts. 1 \& 2), 80 AM J. INT'L L. 913 (1986), 81 AM. J. INT'L L. 371 (1987).

39. Henkin I, supra note 36 , at 931 ; Henkin II, supra note 36 , at 870 .

40. See, e.g., Cook v. United States, 288 U.S. 102, 118-19 (1933); Whitney v. Robertson, 124 U.S. 190, 194 (1888).

41. About self-exeeuting rules of customary international law, see Kirgis, Federal Statutes, Executive Orders and 'Self Executing Custom," 81 AM. J. INT'L L. 371, 372 (1987); contra, however, the concurring opinion of Judge Bork in Tel-Oren v. Libyan Arab Republic, 726 F.2d 774, 817 (D.C. Cir. 1984), cert. denied, 470 U.S. 1003 (1985).

42. The Paquete Habana, 175 U.S. 677 (1900).

43. See Henkin I, supra note 36 , at 933 ("But a supervening principle of customary law will not be denied domestic effect because of some earlier act of Congress."); accord Henkin II, supra note 36, at 878 .

44. Pub. L. No. 99-569, § 106 (1986).

45. Case of Military and Paramilitary Activities In and Against Nicaragua (Nicar. v. U.S.), 1986 I.C.J. 14 (Judgment of June 27, 1986). 
poses, the ICJ judgment notwithstanding. Of course, Congress may limit appropriations to uses authorized by customary international law. Thus the Intelligence Authorization Act for Fiscal Year 1984 provided expressly: "The authorization of appropriations by this Act shall not be deemed authority for the conduct of any intelligence activity which is not otherwise authorized by the Constitution or laws of the United States."46 It would seem that the laws of the Umited States within the meaning of that section include custoinary international law, ${ }^{47}$ inasinuch as customary international law is part of the federal common law. ${ }^{48}$

There remains the question whether the President, in the absence of a specific authorization by Congress to that effect, has the power to enact orders in violation of customary international law and whether the courts have the power to enjoin action taken under such order. Although it has been forcefully argued that the President has no inherent power to issue executive orders in violation of custornary international law and that the courts may invalidate and enjoin the enforcement of such orders, despite apparent judicial authority to the contrary, ${ }^{49}$ it would seein that the argument overshoots the inark. As shown by Professor Kirgis, ${ }^{50}$ a inore nuanced answer seems to be in order. Judicial enforceinent of customary international law against presidential orders is appropriate only in those instances where the Executive is subject to congressional direction. Otherwise the doctrine of separation of powers would be converted into one of absolute judicial supremacy. That does not signify a rule of presides iure gentium solutus, i.e., presidential absolutisin in the conduct of foreigu relations. It means inerely that in the conduct of foreigu relations not all actions of the President are subject to judicial control. It seems to be totally beside the point to discuss the issue in the context of a dualist or inonist approach to mternational law, ${ }^{51}$ because even the theory of the primacy of international law concedes that state action in violation of international law may be entitled to doinestic validity. ${ }^{52}$ Essentially the problem involves the extent to whicls the Constitution adheres to the

46. Intelligence Authorization Act for Fiscal Year 1984, Pub. L. No. 98-215, § 601, 97 Stat. 1473, 1479 (1983).

47. Accord Henkin I, supra note 36, at 933; Henkin II, supra note 36, at 866-70.

48. Banco Nacional de Cuba v. Sabbatino, 376 U.S. 398 (1964).

49. See Glennon, Can the President Do No Wrong?, 80 AM. J. INT'L L. 923 (1986); Glennon, Raising the Paquete Habana: Is Violation of Customary International Law by the Executive Unconstitutional?, 80 Nw. U.L. REv. 321 (1985) (commenting on the famous phrase in The Paquete Habana, 175 U.S. at 700, limiting the application of custonnary international law to situations "where there is no treaty, and no controlling executive or legislative act or judicial decision").

50. Kirgis, supra note 41.

51. Contra Charney, The Power of the Executive Branch of the United States Government to Violate Customary International Law, 80 AM. J. INT'L L. 913, 914 (1986); Henkin I, supra note 36, at 932; Henkin I1, supra note 36, at 864-66.

52. See especially A. Verdross \& B. SIMMA, UNIVERSELles VölKERRECHT \$ $73-74$ (3d ed. 1984). 
doctrine of the separation of powers, a matter so much on the minds of the framers of the document. 